
A
$\mathrm{R}$
$\mathrm{T}$
Y
K
U
Ł

Józef Pociecha

ORCID: https://orcid.org/0000-0003-3140-481X

Cracow University of Economics, Department of Statistics

email: pociecha@uek.krakow.pl

\title{
The Process of Demographic Transition in Lands of the Former Polish-Lithuanian Commonwealth and Other Areas with Polish-Speaking Populations, 1865-1912
}

\author{
Przebieg procesu przejścia demograficznego na ziemiach \\ dawnego państwa polsko-litewskiego oraz na innych obszarach \\ z polskojęzyczną ludnością w latach 1865-1912
}

\begin{abstract}
The aim of the research is to trace the process of demographic transition in the area of the former Polish-Lithuanian Commonwealth, enlarged by areas with a predominantly Polish-speaking population, Upper Silesia and Cieszyn Silesia, as well as Southern Masuria. The time frame of the work covers the years 1865-1912. Changes in the basic indicators of the vital statistics of the population were analyzed: the crude death rate (death rate per 1,000 population), the crude birth rate and the crude marriage rate. The source of the data is the work of Adam Krzyżanowski and Kazimierz Kumaniecki, Statystyka Polski [Statistics of Poland], which was
\end{abstract}

\begin{abstract}
Abstrakt
Celem pracy jest prześledzenie procesu przejścia demograficznego na ziemiach byłego państwa polsko-litewskiego, poszerzonych o obszary zamieszkane głównie przez ludność polskojęzyczną, tj. Górny Śląsk i Śląsk Cieszyński oraz Mazury Południowe. Zakres czasowy pracy obejmuje lata 1865-1912. Przeanalizowano zmiany podstawowych wskaźników ruchu naturalnego ludności, czyli: surowego wskaźnika zgonów (natężenie zgonów na tys. ludności), surowego wskaźnika urodzeń oraz surowego wskaźnika zawierania małżeństw. Źródłem danych jest praca Adama Krzyżanowskiego i Kazimierza Kumanieckiego Statystyka Polski,
\end{abstract}


in fact the first statistical yearbook of the former Polish-Lithuanian Commonwealth and other predominantly Polish-speaking areas. The analysis was carried out strictly according to the requirements of the demographic transition theory. A comparative analysis of the demographic situation in these lands on the eve of the outbreak of World War I was carried out using Ward's taxonomic method and the k-means method. The results of the analysis indicate that the process of demographic transition in these lands was varied and was conditioned by their economic development and geographical location.

\section{Keywords}

historical demography, vital statistics, demographic transition theory, taxonomic methods będąca $\mathrm{w}$ istocie pierwszym rocznikiem statystycznym ziem polskich. Analizę przeprowadzono ściśle według wymogów teorii przejścia demograficznego. Analizę porównawczą sytuacji demograficznej na ziemiach polskich w przededniu wybuchu I wojny światowej przeprowadzono przy zastosowaniu taksonomicznej metody Warda oraz metody k-średnich. Wyniki przeprowadzonej analizy wskazują, że proces przejścia demograficznego na ziemiach polskich przebiegał w sposób zróżnicowany i był uwarunkowany rozwojem gospodarczym oraz położeniem geograficznym tych ziem.

\section{Słowa kluczowe}

demografia historyczna, statystyka ruchu naturalnego, teoria przejścia demograficznego, metody taksonomiczne

\section{The Theory of the Demographic Transition}

A commonly recognized theoretical basis for studying changes in the vital statistics of the population is the theory of demographic transition (demographic transformation). It recognizes that in the historical process of changes taking place in the nineteenth and twentieth centuries, there was a fundamental transformation of the population reproduction process, from the traditional (primitive) phase of reproduction, characterized by high mortality and fertility, through the phase of demographic transition, consisting in a reduction in mortality and, slightly later, fertility, to the modern reproductive phase, characterized by low mortality and low fertility. In the demographic transition phase, the relationship between falling mortality and natural fertility is disrupted, which is accompanied firstly by a rapid increase in the number of the population, and then, along with a decrease in fertility, the pace of population increase slows down until the phase of modern equilibrium is reached. A diagram of this demographic transformation is shown in Figure 1. 
Figure 1. Classic diagram of demographic transition
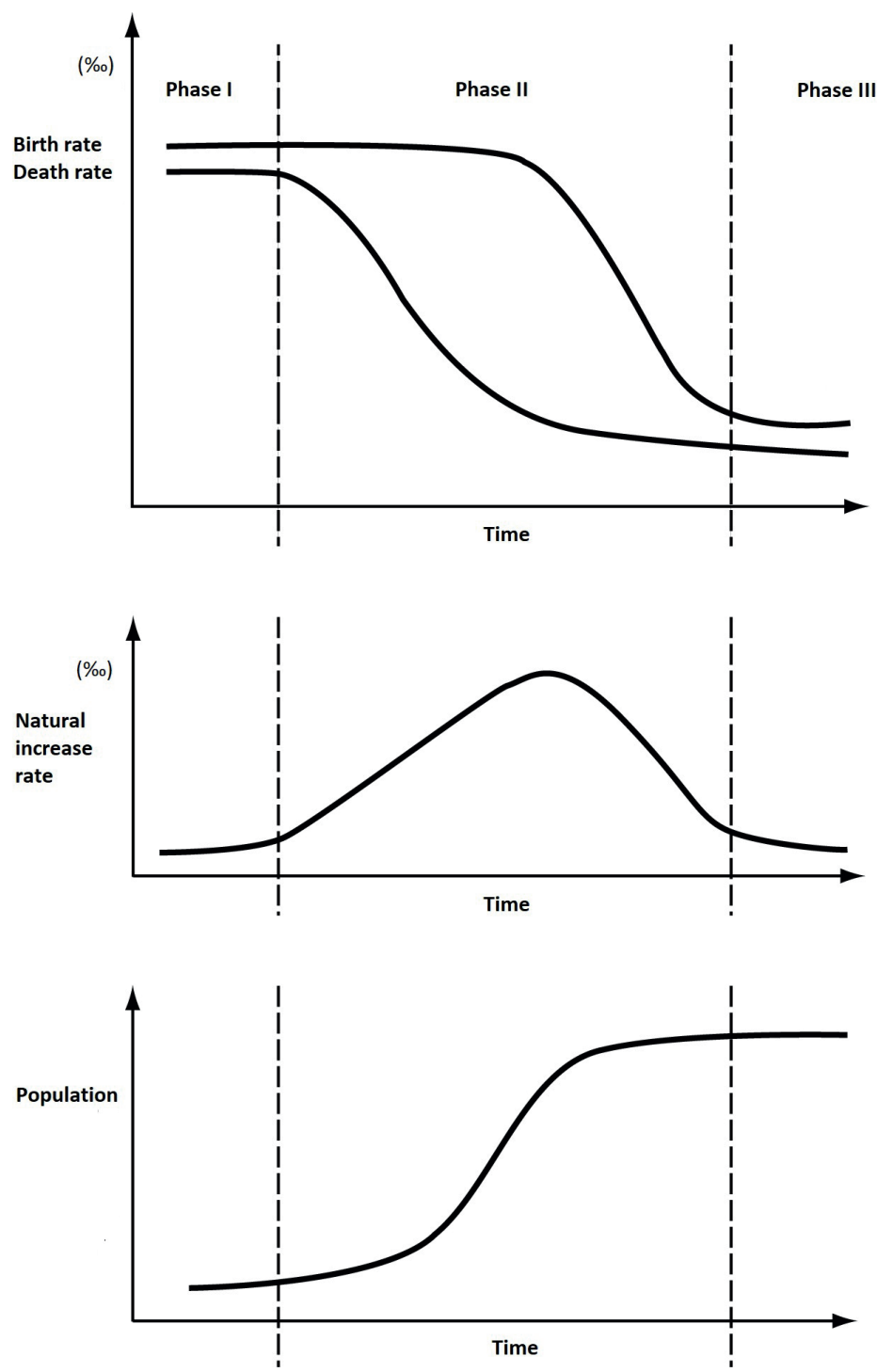

Source: data from Marek Okólski, ed. Teoria przejścia demograficznego (Warszawa: Polskie Wydawnictwo Ekonomiczne, 1990). 
The beginnings of the theory of demographic transition are associated with the independent work of Adolphe Landry in France and Warren S. Thompson ${ }^{2}$ in America. Both presented changes in the processes of mortality and natality in the classic three-phase form. The theory of demographic transition in its mature and classical form was formulated by Frank W. Notestein. ${ }^{3}$

Nowadays in demographic research, the four-phase model of demographic transition ${ }^{4}$ is most often used (Figure 2).

Figure 2. The four-phase model of demographic transition

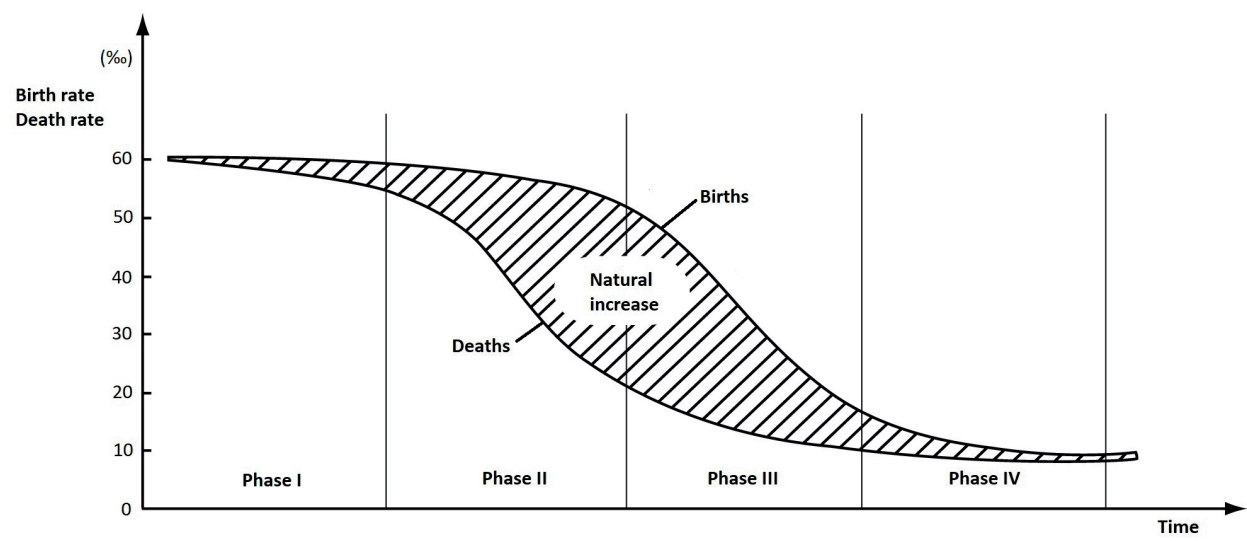

Source: data from Jerzy Z. Holzer, Demografia (Warszawa: PWE, 2003).

In the first phase, we observe the natural process of population reproduction, in which the intensity of births and deaths remains at a high level. In this phase, there is a simple or slightly extended reproduction of the population, and periods in which the mortality rate exceeds the natality rate are also possible. In the second phase, a decrease in mortality is observed, while fertility remains at the current high, natural level, which results in an increasing natural increase in the

${ }^{1}$ Adolphe Landry, La Révolution Démographique. Études et Essais sur les Problèmes de la Population (Paris: Libraire du Recueil Sirey, société anonyme, 1934).

${ }^{2}$ Warren S. Thompson, "Population," American Journal of Sociology 34 (1929), 6: 959-975.

${ }^{3}$ Frank W. Notestein, "Population. The Long View," in: Food for the World, ed. T. Schulz (Chicago: University of Chicago Press, 1945), 36-57.

${ }^{4}$ Ansley J. Coale, The Growth and Structure of Human Populations (Princeton: Princeton University Press, 1972). In Polish, a description of the four-phase model can be found in, among others: Małgorzata Rószkiewicz, Model transformacji demograficznej. Teoretyczne uogólnienia oraz praktyczne implikacje (Warszawa: SGPiS, 1987). 
population. ${ }^{5}$ The third phase is characterized by a faster decrease in the level of fertility than mortality, which results in a declining natural increase in the population. In phase four, the birth rate approaches or exceeds the mortality rate, resulting in zero or negative natural increase.

In the demographic literature, we can find many works in which the theoretical aspects of the demographic transition theory are discussed, its determinants by level of economic and social development, and also problems relating to its empirical verification in geographically, economically, socially and politically diverse countries. ${ }^{6}$

Although the general pattern of demographic transition shown in Figures 1 and 2 is true for all countries, the specific course of changes in the intensity of deaths and births in each country, and even in individual regions of the countries, is different. Empirical demographic research on the course of the demographic transition process in a four-phase approach in various regions of the world, countries and their regions consists in:

- determining the moment of transition of a given society from the first phase to the second i.e., determining the beginning of the demographic transition process;

- determining the moment of transition from the second phase to the third phase, i.e., to the moment when a constant decline in fertility appears;

- determining the moment of transition from the third phase to the fourth, i.e., to the moment when the demographic transition process is completed;

- determination of the mortality curve throughout the demographic transition period;

- determination of the fertility curve throughout the demographic transition period.

${ }^{5}$ The phase of increasing natural increase rate in the demographic literature is equated with a demographic explosion, see e.g., Edward Rosset, Eksplozja demograficzna (Warszawa: Książka i Wiedza, 1978).

${ }^{6}$ The very extensive world literature will not be mentioned here. The basic work presenting general and detailed problems of the demographic transition theory published in Polish is Marek Okólski, ed., Teoria przejścia demograficznego (Warszawa: Polskie Wydawnictwo Ekonomiczne, 1990). Other more important works in Polish on this subject include: Jerzy Z. Holzer, Demografia (Warszawa: PWE, 2003); Jolanta Kurkiewicz, Modele przemian ptodności w wybranych krajach europejskich $w$ świetle drugiego przejścia demograficznego (Kraków: Wydawnictwo Akademii Ekonomicznej w Krakowie, 1998); Jolanta Kurkiewicz, ed., Procesy demograficzne i metody ich analizy (Kraków: Wydawnictwo Uniwersytetu Ekonomicznego w Krakowie, 2010); Marek Okólski, Demografia (Warszawa: Wydawnictwo Naukowe Scholar, 2005). An interesting work presenting the model and course of demographic transformation in the context of the course of long-term demographic processes in Kraków at the turn of the 19th and 20th centuries is Bartosz Ogórek, Niezatarte piętno? Wplyw I wojny światowej na ludność miasta Krakowa (Kraków: Universitas, 2018). 
Accurate determination of the mortality and natality curves requires a knowledge of crude mortality rates and crude birth or total fertility rates over long periods of time, which is often difficult to achieve, especially in long-gone times or in countries with a low degree of political organization. It is slightly easier to approximate the transition boundaries to particular phases, as this requires knowledge of the relevant coefficient values only in breakthrough periods. Many works have been devoted to the study of the demographic transition process in world literature. Among them, the most important is the extensive work of JeanClaude Chesnais, ${ }^{7}$ who collected extensive statistical material on the course of the demographic transition process in 67 countries covering the period 1720-1984.

The purpose of this work is to show the approximate course of the demographic transition process in the various regions of the former Polish-Lithuanian Commonwealth and other predominantly Polish-speaking areas from the mid-nineteenth century to the outbreak of World War I and to show the similarity and diversity of the process in the distinguished administrative units on the eve of the outbreak of World War I.

\section{Statystyka Polski as a Source of Study of the Demographic Transition Process}

In 1912, in Kraków, statisticians and economists from all partitions established an association of Polish statisticians under the name of the Polskie Towarzystwo Statystyczne [Polish Statistical Association, hereafter referred to as the PTS]. ${ }^{8}$ Its first president, Dr. Juliusz Leo, was elected Professor of the Treasury at the Jagiellonian University, Mayor of the City of Kraków and was an outstanding conservative politician.

One of the basic goals of the PTS was to publish social statistical yearbooks for the former Polish-Lithuanian Commonwealth and other areas with Polish-speaking populations. At the end of the partitions, there were quite extensive and reliable demographic, social and economic data on the territory of the Polish state which, at that time, did not officially exist. However, the data were scattered around the publications and statistical sources of the partitioning states.

\footnotetext{
${ }^{7}$ Jean-Claude Chesnais, La transition démographique. Étapes, formes, implications économiques (Paris: Presses Universitaires de France, 1986).

${ }^{8}$ Many works are devoted to the history of the PTS, including Czesław Domański, Jubileusz Polskiego Towarzystwa Statystycznego, in: Tradycje i obecne zadania statystyki $w$ Polsce, ed. Alexander Zeliaś (Kraków: Wydawnictwo Akademii Ekonomicznej w Krakowie, 2004); Józef Pociecha, "Powstanie Polskiego Towarzystwa Statystycznego w Krakowie: J. Leo - pierwszy prezes Towarzystwa," Wiadomości Statystyczne 10 (2011); Polskie Towarzystwo Statystyczne 1912-1992 (Warszawa: Polskie Towarzystwo Statystyczne, Rada Główna, 1992).
} 
The PTS decided to verify, merge and, if possible, supplement these data. Such studies were to be published by the PTS in the form of statistical yearbooks for these lands. Before the outbreak of World War I, PTS compiled such a statistical yearbook, entitled Statystyka Polski, printed during the war, in 1915, at the Jagiellonian University Press. ${ }^{9}$

The authors of Statystyka Polski later became very famous Polish professors: Prof. Adam Krzyżanowski and Prof. Kazimierz Władysław Kumaniecki. In addition to these main authors, other persons known at that time or later, such as Prof. Franciszek Bujak, Prof. Stanisław Surzycki and Prof. Edward Grabowski were involved in the editorial committee. Collaborators in the editorial committee also included Dr. Marcin Nadobnik from Lviv and Michał Römer from Vilnius. The project was supported by such contemporary personalities as Prof. Władysław L. Jaworski, Prof. Stanisław Kutrzeba, Prof. Michał Rostworowski and Dr. Franciszek Stefczyk. The tabulation was made by employees at the Miejskie Biuro Statystyczne [Municipal Statistical Office] in Kraków. Statystyka Polski was thus the work of people representing all the partitions, but the dominant role was played by Galician statisticians and economists. ${ }^{10}$ Statystyka Polski was published in a trilingual Polish, German and French version. The intention of the authors was therefore to disseminate the work in an international environment. This publication was later used as a Polish argument to define the borders of the reborn Polish state at the Peace Conference in Paris which ended with the signing of the Versailles Treaty.

It is important to define the territorial and temporal scope of the data contained in Statystyka Polski. The authors of the work write about this in the Foreword: "Defining the scope of our spatial combinations raised many doubts. [...] In order to present Poland in statistical figures, we first of all had to answer the question of which territorial areas will become the subject of our research. We had two paths to choose from: historical and ethnographic. We were able to display statistically the relations on the lands that used to be part of the Polish-Lithuanian Commonwealth or on lands inhabited today by Poles. We chose the indirect path in the belief that in this way we would avoid the one-sidedness of relying solely on the historical or ethnographic principle. In our lists, we have covered mainly the lands of the former Polish-Lithuanian Commonwealth: Galicia, the Kingdom of Poland (Congress Poland), the Prussian Kingdom regions of Poznan and Royal Prussia, as well as Lithuania, Belarus and three governorates which were formerly Ruthenian provinces: Podole, Wołyń and Kiev region; we did not

\footnotetext{
${ }^{9}$ Adam Krzyżanowski, Kazimierz Kumaniecki, Statystyka Polski (Kraków: Polskie Towarzystwo Statystyczne, 1915).

${ }^{10}$ Józef Pociecha, "Statistics of Poland - The First Yearbook of Polish Lands: Authors and Content," Acta Universitatis Lodziensis. Folia Oeconomica 5 (2018), 338: 229-245.
} 
omit the countries inhabited to a large extent by Poles, which have long ceased to be part of the Polish state. We did not omit the Olsztyn Region or the Cieszyn and Opole Districts in Silesia. [...] Due to the difficulties in collecting reliable material, we did not include Poland in exile, a large group of Poles living within the three partitioning states, but outside the areas we excluded in our calculations, in Bukovina, in the Rhenish provinces, in Berlin and St. Petersburg, and also in North and South America. The lists do not cover the whole of Polish society, nor do they include all the people whose mother tongue is Polish, because we did not want to reach beyond the territorial limits set out in our work. We included the entire population living within these borders, so we did not limit ourselves to the statistics of Polish society only. In the area statistically enumerated in our book, there live, alongside Poles, people whose mother tongue is not Polish. It would not be possible to separate Poles from the general population living in the lands of the former First Republic, Opole and Cieszyn Silesia, the Olsztyn Region and would not be desirable, even." 11

When it comes to the time scope of Statystyka Polski, the authors write that they wanted to "illustrate the present state of affairs", that is, from the period before the First World War. However, as they point out: "In order to facilitate the understanding and assessment of the present, we have reached back within the limits indicated by the nature and size of the work. The Reader will find most retrospective statistics in the first part, covering the state and movement of the population. Historical statistical material is more abundant in this section than in others. We did not go back beyond 1815 - the limit imposed by the available material." $" 12$

As is clear from these excerpts from the preface to Statystyka Polski, which is the source of the statistical data, the territorial scope of this study includes lands understood as the territory of the First Republic within the borders before the first partition (1772), extended by the territories of Upper Silesia (Opole Region), Cieszyn Silesia and Southern Mazuria (Olsztyn Region), inhabited mostly by Polish populations. However, it should be emphasized that in some historically Polish lands, such as Lithuania, Belarus, Ruthenia or Royal Prussia, the Polish population was in the minority. The time scope of this article covers the period of the second half of the 19th century until the outbreak of World War I.

\footnotetext{
${ }^{11}$ Krzyżanowski, Kumaniecki, Statystyka, XXIV-XXV (own translation).

${ }^{12}$ Ibidem, XXV (own translation).
} 


\section{Vital Statistics of the Population}

The basic demographic process shaping the size and structure of the population is the vital statistics of the population..$^{13}$ This mainly includes births and deaths, but the birth process is carried out mainly within marriages, so traditionally the vital statistics also includes entering into (dissolving) marriage. Vital statistics events have long been continuously registered, firstly by religious institutions and now in registry offices. Data on vital statistics are relatively most accessible and more reliable than other socio-economic characteristics of the population.

In Statystyka Polski, statistical data on the intensity of marriages, births, deaths and natural increase as the difference between births and deaths, for the individual districts of the lands in the period under analysis, are included in tables T. $43-$ T. 50 on pp. $72-80$. On their basis, the course of the individual processes of vital statistics in the lands will be traced. As a result, an attempt will be made to trace the demographic transition process in individual districts of Polish-speaking lands territorially defined by the scope of data included in Statystyka Polski.

The territory of the lands under Russian partition includes the following: The Kingdom of Poland, Lithuania and Belarus (governorates: Vilnius, Kaunas, Grodno, Minsk, Mogilev, Witebsk), Ruthenia (governorates: Volynia, Podolia, Kiev). The territorial units belonging to Austria are: Galicia and Cieszyn Silesia. The lands under Prussian partition are: Poznań (Grand Duchy of Poznań), Pomerania (Royal Prussia) and Upper Silesia (Opole Region, German: Regierungbezirk) and Southern Masuria (Olsztyn Region, German: Regierungsbezirk). The time range covers the period from 1861 to 1912, the data from the 19th century are given as averages from each of the four decades and assigned to the middle years of individual decades, and in the 20th century two-year periods were adopted. Statistical data on individual districts and periods are incomplete. These are also secondary data, drawn from various sources. The authors of Statystyka Polski detail the sources of the data, so they will not be cited here. The degree of reliability of these data varies. Data on lands under German rule are generally considered reliable, as the Prussian Statistical Office was considered at the time to be the exemplary European statistical office. Austrian statistics were also considered reliable at that time. However, reservations can be made about the data for the lands under Russian partition. Generally, it can be assumed that these data illustrate well the tendencies of changes and differences in the intensity of the vital statistics of the population, but the credibility of the specific values of individual

\footnotetext{
${ }^{13}$ The topic of vital statistics and the methods of its measurement are discussed in many demographic textbooks. Recommended Polish titles include: Maria Cieślak, ed., Demografia. Metody analizy i prognozowania (Warszawa: Wydawnictwo Naukowe PWN, 1992); Holzer, Demografia; Kurkiewicz, Procesy; Okólski, Demografia.
} 
demographic indicators may differ. For this reason, detailed figures on the vital movement of the population will not be provided here. ${ }^{14}$ The values of the demographic parameters in these districts in this time range are given in Figures 3-6.

The beginning of the demographic transition is determined by changes in the intensity of deaths. Figure 3 shows the trends of changes and differences in the values of the crude death rate.

Figure 3. Intensity of deaths in individual districts of the former Polish-Lithuanian Commonwealth and other predominantly Polish-speaking areas in the years 1865-1912

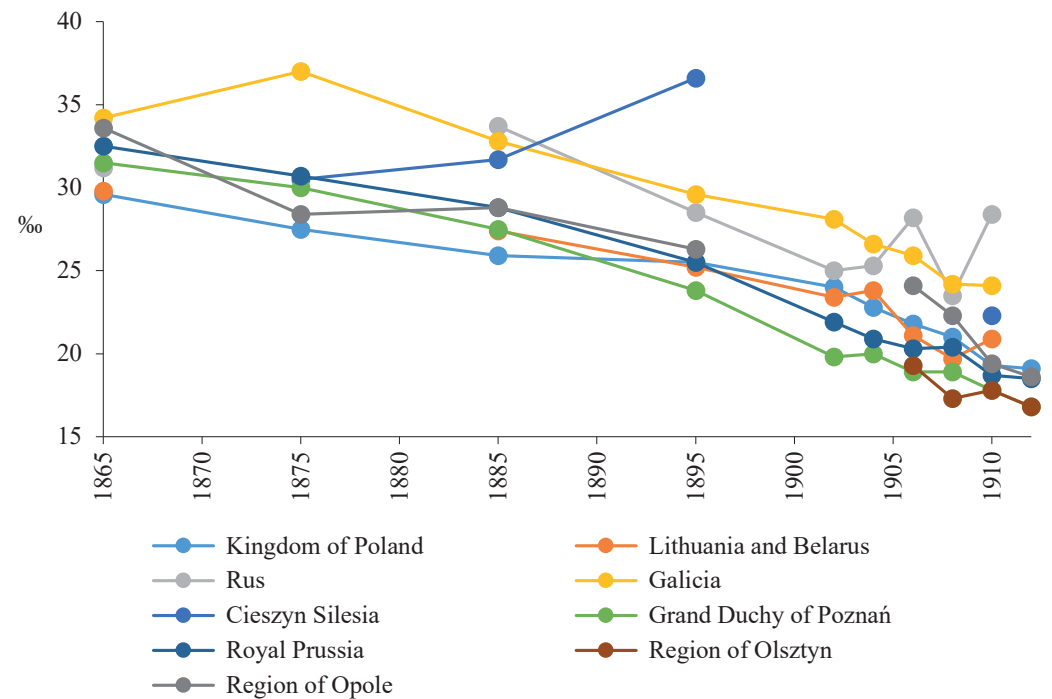

Source: Krzyżanowski, Kumaniecki, Statystyka, table 48, and own calculations.

The transition from the second to the third phase of the demographic transformation marks the beginning of a constant downward trend in the birth rate. The course of changes and the differences in the values of the crude birth rate in individual districts of the historically Polish-speaking areas are shown in Figure 4.

The difference between the number of births and the number of deaths is the natural increase. The tendencies of changes and differences in the values of the natural increase rate in individual districts are given in Figure 5.

${ }^{14}$ Detailed data can be found in Krzyżanowski, Kumaniecki, Statystyka, 72-80. 
Figure 4. The intensity of births in individual districts of the former Polish-Lithuanian Commonwealth and other predominantly Polish-speaking areas in the years 1865-1912

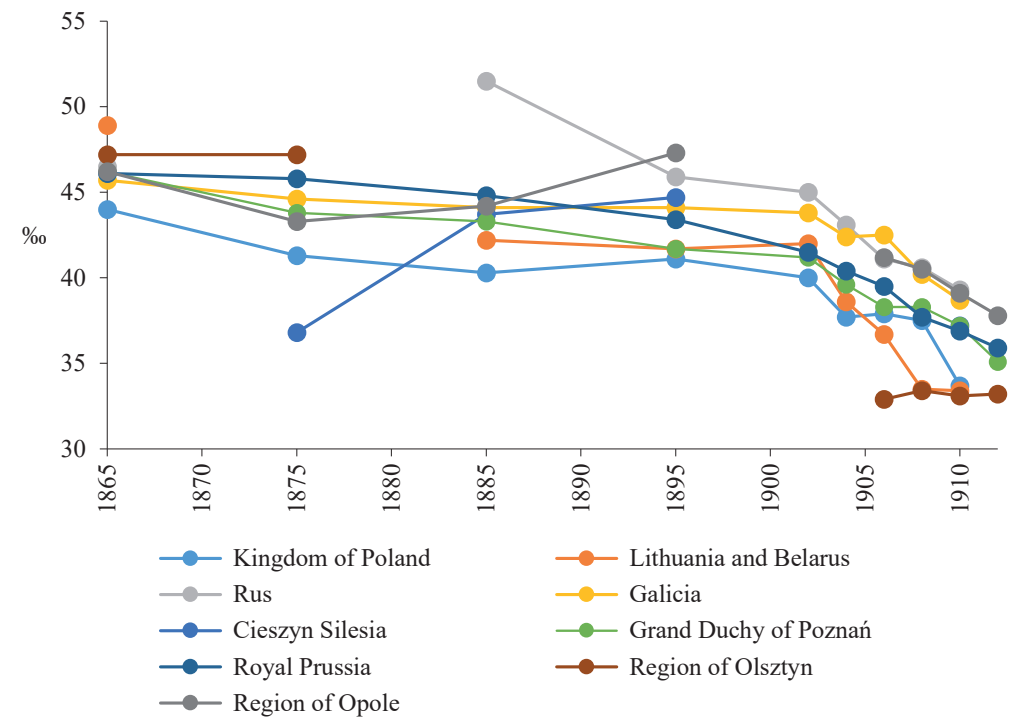

Source: Krzyżanowski, Kumaniecki, Statystyka, table 46, and own calculations.

Figure 5. Natural increase in population (per mille) in individual districts of the former Polish-Lithuanian Commonwealth and other predominantly Polish-speaking areas, 1865-1912

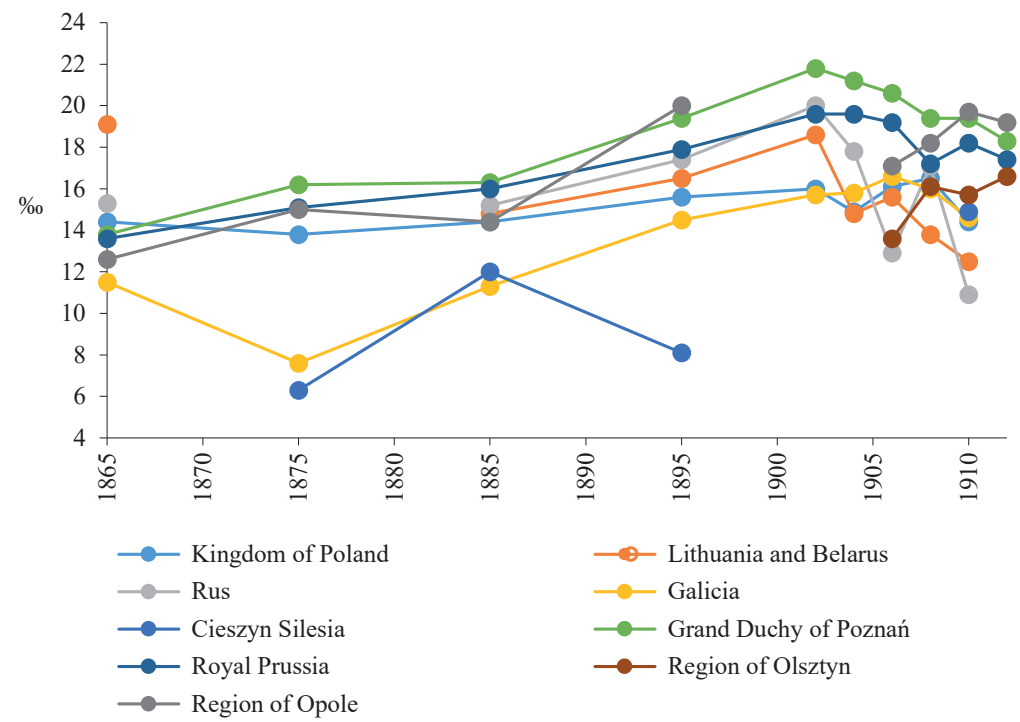

Source: Krzyżanowski, Kumaniecki, Statystyka, table 50, and own calculations. 
The traditional analysis of the vital statistics of the population also includes the study of the intensity of marriages. The crude marriage rates in each district during the period considered are shown in Figure 6.

Figure 6 . The intensity of marriages in individual districts

of the former Polish-Lithuanian Commonwealth and other predominantly Polish-speaking areas, 1865-1912

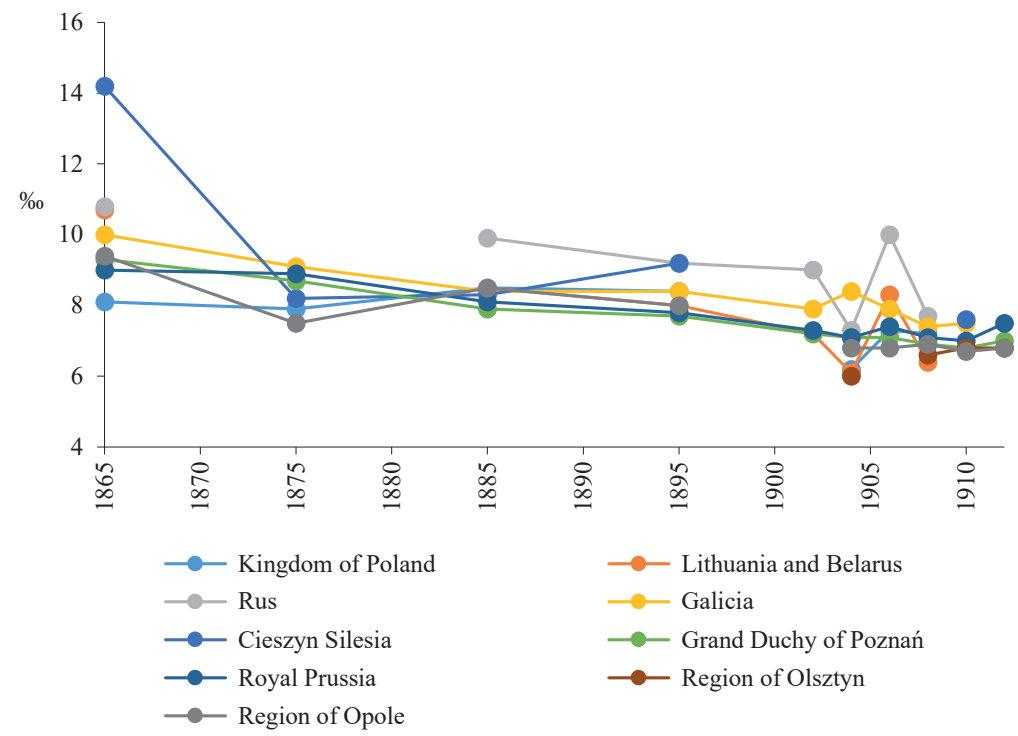

Source: Krzyżanowski, Kumaniecki, Statystyka, table 44, and own calculations.

With the data contained in the source tables and the drawings above, we will try to answer the following questions:

1. In which districts of the former Polish-Lithuanian Commonwealth and other predominantly Polish-speaking areas is the demographic transition process apparently revealed?

2. When did the process of demographic transition begin in particular districts of the former Polish-Lithuanian Commonwealth and other predominantly Polish-speaking areas?

3. When and where did the transition from the second to the third phase in four-phase model of demographic transition take place, if at all?

An analysis of the drawings shows that the process of the demographic transition in Poland was not clear, it was disrupted by the influence of many other factors, including the low level of economic development, famine, epidemics, waves 
of emigration from Polish-speaking lands or political disturbances in the Russian partition (the 1905 Revolution, Russo-Japanese War). The most regular course of the demographic transformation, similar to the four-phase model of transition, took place in Greater Poland (the Grand Duchy of Poznań). It is also clearly visible in Pomerania (Royal Prussia). Figure 7 shows the course of the demographic transition in Greater Poland (Grand Duchy of Poznań).

Figure 7. The process of demographic transition in Greater Poland (the Grand Duchy of Poznań), 1865-1912

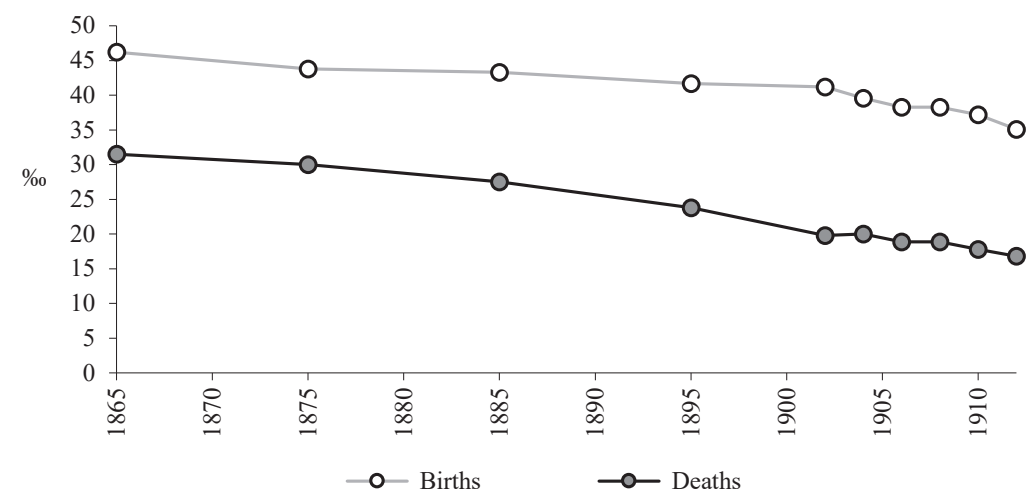

Source: Krzyżanowski, Kumaniecki, Statystyka, table 46, table 48, and own calculations.

Answers to the question on the demographic transition process in these historically Polish-speaking areas should also be sought in international and Polish literature. The main work in this field is the book by Jean-Claude Chenais. ${ }^{15}$ The author conducted extensive comparative studies of the demographic transition process in many countries of the world including Austria, Germany and Russia, which included the Polish-Lithuanian Commonwealth and other areas with Polish-speaking populations during the partitions. In Europe, he distinguished three types of transition: Nordic, Western, to which he included the then (1986) German states (West Germany, East Germany), Austria, Hungary and Poland, and Southern or Eastern, to which he included the then USSR. He characterized the Western type as a transformation with a long transition period (around 100 years) and a maximum natural increase at the turn of the 19th and 20th centuries. The Southern or Eastern type was characterized as having a fairly long transition period (70-90 years), with the maximum natural increase only in the 20th

${ }^{15}$ Chesnais, La transition. 
century ${ }^{16}$. Works devoted to an analysis of the demographic transition process in Germany include, among others, the work by John E. Knodel, ${ }^{17}$ but there we can only find information on particular regions of Germany. Therefore, we can state that in the international literature there is no further information on the course of the demographic transition process in historically Polish regions.

Polish literature on the study of the demographic transformation in Poland is quite modest. The most important works were by Krzysztof Zamorski, ${ }^{18}$ based on the same demographic database, ${ }^{19}$ in which the author traced changes in the population number, population density, age structure, marriage, births and deaths in Galicia compared to other Central European regions such as Cisleithania, Greater Poland, the Kingdom of Poland, Austrian and Prussian Silesia. This work did not directly refer to the theoretical model of demographic transition. Elżbieta Stańczyk ${ }^{20}$ traced the fertility and mortality in Poland from 1895 to 1938 in the context of the theory of demographic transition. An article by Piotr Eberhard ${ }^{21}$ presents the long-term demographic changes taking place in Poland in the fivephase cycle of demographic transformation in the period from the second decade of the 19th century to the first decade of the 21st century. Regarding the period of interest to us, the second half of the nineteenth century to the first decade of the twentieth century, the author states, "Until World War I, the lands of the former Polish-Lithuanian Commonwealth and other areas with Polish-speaking populations were in the second phase of transformation of natural movement, which consisted in a slight decrease in the number of births with a simultaneous faster decrease in mortality." 22 Of course, in the Polish literature we can find a number of other works on changes in the individual components of the vital statistics in different territorial systems, which will not be mentioned here.

Moving on to the question of when the demographic transition started, its beginnings, at least in the privileged social strata of Western Europe, can be seen as

\footnotetext{
${ }^{16}$ Okólski, Teoria, 99.

${ }^{17}$ John E. Knodel, The Decline of Fertility in Germany 1871-1939 (Princeton: Princeton University Press, 1974).

${ }^{18}$ Krzysztof Zamorski, Transformacja demograficzna w Galicji na tle przemian ludnościowych innych obszarów Europy Środkowej w drugiej połowie XIX i na początku XX w. (Kraków: Wydawnictwo Uniwersytetu Jagiellońskiego, 1991); idem, "Transformacja demograficzna w Europie Środkowej w XIX w. Wewnętrzne podobieństwa i różnice,” Przeszłość Demograficzna Polski 19 (1994): 27-45.

${ }^{19}$ Krzyżanowski, Kumaniecki, Statystyka.

${ }^{20}$ Elżbieta Stańczyk, "Rodność i umieralność na ziemiach polskich w kontekście teorii przejścia demograficznego, Wiadomości Statystyczne 9 (2009): 16-32.

${ }^{21}$ Piotr Eberhard, "Fazy rozwoju demograficznego Polski," Roczniki Nauk Społecznych 42 (2014), 2: 135-160.

${ }^{22}$ Ibidem, 141 (own translation).
} 
early as the 17 th and 18 th centuries. ${ }^{23}$ However, as demographers say quite unanimously, "Actual changes began only after 1870, showing an extremely strong territorial differentiation, within and between countries, but at the same time covering almost all European countries at relatively short intervals." ${ }^{24}$ Krzysztof Zamorski, ${ }^{25}$ when discussing the beginnings of the demographic transformation in the lands of the former Polish-Lithuanian Commonwealth and other areas with Polish-speaking populations, states that their populations had a quarter-century delay in relation to Western Europe.

By focusing on the data contained in Statystyka Polski and Figures 3-5, the transition from the first to the second phase of demographic transformation in lands of the former Polish-Lithuanian Commonwealth and other areas with Polish-speaking populations will be traced. A decrease in the intensity of deaths in relation to the initial level, adopted here conventionally for the year 1865 , can be observed by the mid-1870s in the Poznań region (a decrease in the crude death rate from about 31.5 per mille in 1865 to 16.8 per mille in 1912, i.e., a decrease in the intensity of mortality by 14.7 deaths per thousand inhabitants). A similar, or even slightly greater, decrease in the intensity of deaths is observed in Upper Silesia (Opole Region), by 15.0 deaths per thousand residents. Also in Pomerania (Royal Prussia), there was a similar decrease, by 14 per mille. Changes in mortality in the Olsztyn Region are subject to some uncertainty due to a lack of relevant data until the beginning of the 20th century. However, the crude death rate in individual districts of these historically Polish-speaking areas under the rule of the German Empire in 1912 was very similar (Poznań, 16.8; Upper Silesia, 18.6; Pomerania, 18.5; Masuria, 16.8). These results generally concur with Knodel's findings ${ }^{26}$ that the process of demographic transition began more or less at the same time in eastern Germany.

The process of demographic transition in the lands under Russian partition was somewhat different. Here, too, there are significant differences between the Kingdom of Poland and the eastern territories taken from the First Republic of Poland. In the Kingdom of Poland, the process of demographic transition also began relatively early, in the mid-1870s, but the decline in mortality was slower here than in the lands under German partition. The fall in the crude death rate was 10.5 deaths per thousand inhabitants (from about 29.6 per mille in 1865 to 19.1 per mille in 1912). In Lithuania and Belarus, the transition process started in the mid-1990s and was even slower (a drop in the crude death rate by 8.9 per mille)

${ }^{23}$ Okólski, Teoria, 22-25.

${ }^{24}$ Okólski, Demografia, 129.

${ }^{25}$ Krzysztof Zamorski, "Początki przejścia demograficznego w Polsce," Studia Demograficzne 2 (1993): 15-22 (own translation).

${ }^{26}$ Knodel, The Decline. 
over the period under review. In Ruthenia (in the Ruthenian governorates of the Russian Empire), we observe the beginnings of demographic transition around the mid-nineties, and the decline in mortality in this period is very slow, by 2.8 per mille, and is subject to relatively large fluctuations during this period.

The process of demographic transformation in Galicia was also different. Here, it began in the mid-1880s, and the decrease in the mortality rate was 10.1 per mille. It had the highest mortality in Poland in the $1860 \mathrm{~s}$, amounting to 34.2 deaths per thousand people, up to 24.1 deaths per thousand people in 1910, which was also the highest mortality (apart from the mortality in Ruthenia) in historically Polish regions. Due to gaps in the data, we cannot follow the process of demographic transition in Cieszyn Silesia. It can only be noted that between the mid-1870s and 1910 there was a decrease in mortality by 8.2 per mille (from 30.5 per mille in the mid-seventies to 22.3 per mille in 1910).

The next step in our analysis is to determine the approximate moment of transition from the second to the third phase in the four-phase model of demographic transformation, i.e., the moment when the birth rate declined significantly. This is equivalent to finding the maximum rate of natural increase. The results will be presented in the same order as before in the individual historical districts of Poland.

In Greater Poland (the Grand Duchy of Poznań), the beginning of the third phase of the demographic transition can be dated to the beginning of the 20th century. In the period 1902-1912, the crude birth rate dropped from 41.2 per mille to 35.1 per mille and the natural increase of the population fell from 21.8 per mille to 18.3 per mille, but it was still significantly higher than at the beginning of the period under discussion (in the mid-1860s it was 13.8 per mille). For Upper Silesia (Opole Region) it is difficult to determine this turning point, as there are no data for 1902, but it can be assumed that it falls more or less at the end of the first decade of the 20th century. The crude birth rate between the mid-1890s and 1912 fell by 9.5 per mille, but the natural increase rate only fell by less than 1 per mille, as more or less the same proportion between births and deaths was maintained during this period. In Pomerania (Royal Prussia), the transition from the second to the third phase is the beginning of the 20th century. The decrease in the intensity of births between 1902 and 1912 was 5.6 per mille, and the decline in the natural increase rate was 2.2 per mille. For the Olsztyn Region, we cannot determine this moment of transition due to a lack of data.

In the Kingdom of Poland, the transition from the second to the third phase was somewhat different. The beginning of the decrease in births also occurred at the beginning of the 20th century, but the decrease in the natural increase rate in the first decade of the 20th century was minimal (from 16.0 per mille in 1902 to 14.4 per mille in 1910), i.e., the decline in births was approximately proportional 
to the decline deaths. It can also be noted that the natural increase in the Kingdom of Poland at the beginning of the period, 1865, and at the end, 1910, was the same (it was 14.4 per mille). In Lithuania and Belarus, the transition from the second to the third phase took place at the beginning of the first decade of the twentieth century, and the decrease in the birth rate was more significant (from 18.6 per mille in 1902 to 12.5 per mille in 1910). In Ruthenia, this transition also occurred at the beginning of the 20th century, and the decrease in the rate of natural increase was significant (from 20 per mille in 1902 to 10.9 per mille in 1910).

In Galicia, the transition from the second to the third phase occurred at the end of the first decade of the 20th century. Due to the gaps in data, we cannot mark this transition for Cieszyn Silesia.

When it comes to the number of marriages per thousand population (Figure 6), a decrease in the number of marriages can be observed in the period 1865-1912, especially until the $1880 \mathrm{~s}$, which can be associated with the beginning of the demographic transition determined by the decrease in mortality (including mortality of spouses) and the same number of remarriages.

The analysis of the data on fertility and mortality shows that in the historically Polish-speaking areas the process of demographic transition took place in a different way between particular partitions, but also within partitions. These differences occurred both in terms of the start date of the transformation and the moment of transition from the second to the third phase, as well as the levels of values of individual vital statistics indicators and the rate of their changes. It can therefore be concluded that even in a relatively small area of Central and Eastern Europe such as the territory of the First Republic and Polish-speaking areas, the process of demographic transformation was varied both in terms of time and in terms of the pace of change.

To sum up our analysis of the vital statistics of the population in the former Polish-Lithuanian Commonwealth and other areas with Polish-speaking populations, it should be emphasized that until the outbreak of World War I, natural increase was still high and no symptoms of transition to the fourth phase of demographic transformation, i.e., modern reproduction, were noticeable. World War I interrupted the continuity of the demographic transition in Poland. After the interwar period, World War II caused another break in the continuity of demographic processes. Demographers assume that the vital statistics indicators entered the declining phase of the demographic transformation from the beginning of the 1960s, and in the early 1990s the process of demographic transition in Poland was finally and irrevocably completed. ${ }^{27}$ Contemporary changes in the vital

\footnotetext{
${ }^{27}$ Eberhard, "Fazy," 147.
} 
statistics of the population are described by the theory of the second demographic transition..$^{28}$

In studying changes in the vital statistics, an important role is played by the study of the total similarity and diversity of the demographic indicators. Therefore, the question arises as to whether it is possible to distinguish certain similar groups of territorial units due to the course and degree of advancement of the demographic transition process in the former Polish-Lithuanian Commonwealth and other areas with Polish-speaking populations? Taxonomic methods of grouping objects can be a useful tool in finding an answer to the above question.

\section{A Taxonomic Analysis}

Taxonomic methods are multidimensional classification procedures. Specifically, they are methods of extracting groups of similar objects in a space with multidimensional features. They are a widely recognized tool for studying multidimensional structures in many academic fields, such as the natural, socio-economic, psychological and human sciences, including historical sciences. ${ }^{29}$ Literature on taxonomic methods is readily available and extensive. ${ }^{30}$ Currently, in line with global trends, these methods are called ${ }^{31}$ cluster analysis.

In our analysis of historical data on the demographic transition, let us ask the following question: Is it possible to distinguish certain groups of territorial units included in historically Polish-speaking areas, which are very similar due to the course of the demographic transformation processes on the eve of World War I? The subject of classification here will be nine territorial units of historically Polish lands (the Kingdom of Poland, Lithuania and Belarus, Ruthenia, Galicia, Cieszyn Silesia, the Grand Duchy of Poznań, Royal Prussia, Olsztyn Region and Opole Region). The classification space will be three-dimensional for the

\footnotetext{
${ }^{28}$ The most comprehensive of the works in Polish is: Kurkiewicz, Modele.

${ }^{29}$ An example would be the work by Lucyna Błażejczyk-Majka, Zastosowanie wybranych metod taksonomicznych $w$ badaniach historycznych (Poznań: Wydawnictwo Instytutu Historii Uniwersytetu im. Adama Mickiewicza w Poznaniu, 2018).

${ }^{30}$ The Polish literature recommends, inter alia, works by: Tadeusz Grabiński, Stanisław Wydymus, Aleksander Zeliaś, Metody taksonomii numerycznej w modelowaniu zjawisk społeczno-ekonomicznych (Warszawa: PWN, 1989); Maria Kolenda, Taksonomia numeryczna (Wrocław: Wydawnictwo Akademii Ekonomicznej we Wrocławiu, 2006); Andrzej Młodak, Analiza taksonomiczna w statystyce regionalnej (Warszawa: Difin, 2006); Józef Pociecha et al., Metody taksonomiczne w badaniach społeczno-ekonomicznych (Warszawa: PWN, 1988).

${ }^{31}$ Analiza skupień - Internetowy podręcznik statystyki, http://www.statsoft.pl.
} 
following characteristics: crude death rate, crude birth rate, and crude marriage rate per thousand people. ${ }^{32}$

In order to distinguish homogeneous groups within the territorial units of these areas, Ward's hierarchical agglomerative clustering method and alternatively the $k$-means clustering method ${ }^{33}$ were used. Ward's method analyzes the variance of clusters and is considered a very effective procedure for grouping objects. If we assume a number of groups $k$, into which we want to divide our set of objects, then the $k$-means method is the procedure that allows us to determine the $k$ groups that differ to the greatest extent in the feature space.

The results of the classification for the nine territorial units, achieved using Ward's method, defining the vital statistics of the population in the feature space, and assuming the Euclidean distance for the measure of their distance, are shown in Figure 8.

Figure 8. Dendrogram of the former Polish-Lithuanian Commonwealth and other areas with Polish-speaking populations made with Ward's taxonomic method for the Euclidean distance

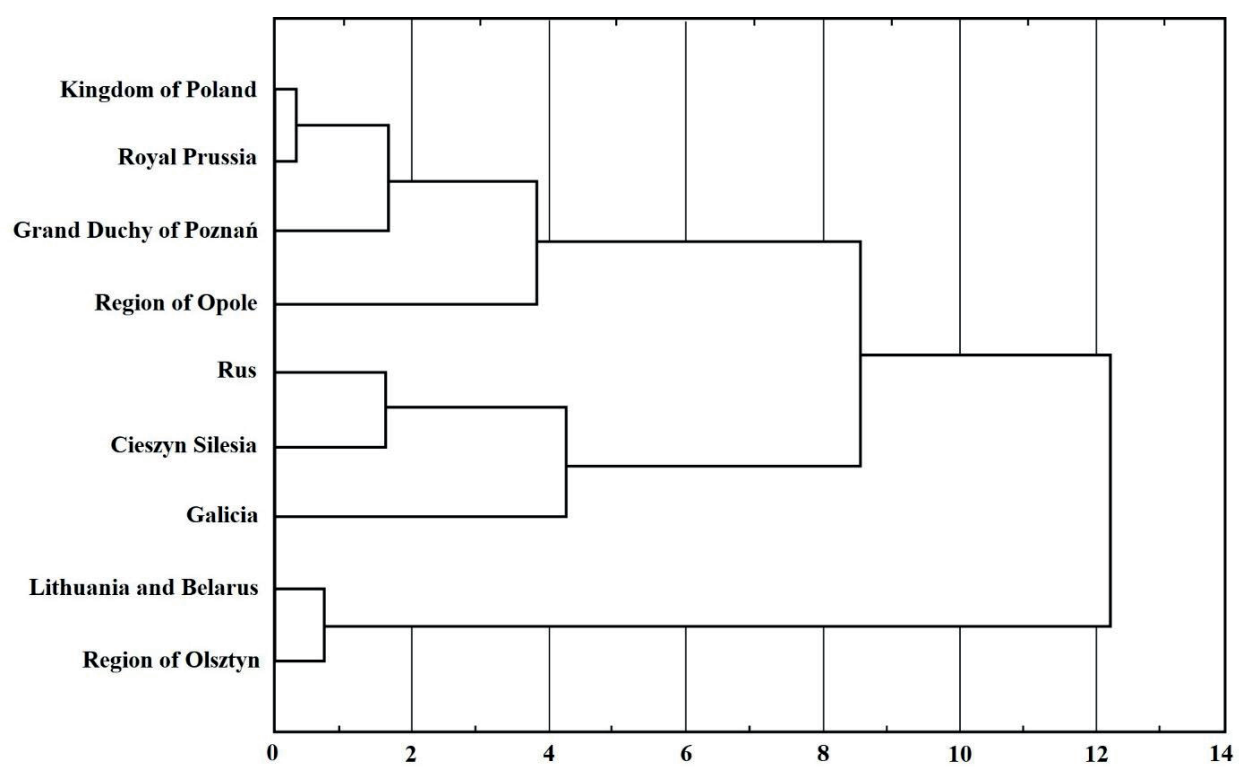

Source: own calculations.

${ }^{32}$ These data, the source of which is: Krzyżanowski, Kumaniecki, Statystyka, tab. 44-48, pp. 74-78 have been partially recalculated and refer to the year 1910/1911.

${ }^{33}$ For a comprehensive description of these methods, see Analiza skupień. 
Figure 8 clearly distinguishes three groups of territorial units due to the course of the demographic transformation, described by the values of the mortality, fertility and nuptiality rates in 1910/1911. The first group is the Kingdom of Poland, Royal Prussia, the Great Duchy of Poznań and Opole Region (Upper Silesia). The second group is Ruthenia, Cieszyn Silesia and Galicia. The third group is Lithuania and Belarus, and Olsztyn Region (South Masuria).

The results of the classification into three groups of territorial units using the $k$-means method are as follows: the Kingdom of Poland, Royal Prussia, the Great Duchy of Poznań, Opole Region, and Cieszyn Silesia. The second group is Ruthenia and Galicia. The third group is Lithuania and Belarus as well as Olsztyn Region.

If we interpret the results of the grouping according to the advancement of the demographic transition process, we can see that the division by partitioning powers is not a decisive factor. A more important factor is the level of economic development in these lands. The first group includes lands with a higher level of economic development, belonging to the German partition, but also the Kingdom of Poland. The influence of the geographic and natural factors is also clear. The first group includes the western and central lands of the First Polish Republic, the second group includes the southern lands, and the third group includes the north-eastern lands, which is generally consistent with the theoretically separated types of transition ${ }^{34}$ into Western, Southern and Eastern types. The classification results obtained with Ward's method and the $k$-means method differ only in the different classification of Cieszyn Silesia. Ward's method connects Cieszyn Silesia with other southern territories of the Republic of Poland, and the $k$-means method connects Cieszyn Silesia with the more economically developed western territories of the Republic of Poland.

The next stage of research may be the use of taxonomic methods to periodize the course of the demographic transformation process, i.e., the use of dynamic taxonomy methods. It is also important to search for socio-economic or geographic and natural features which significantly affect the course of the demographic transformation process, and which can be studied using taxonomic methods of selecting features. ${ }^{35}$ However, the inclusion of the time factor and the taxonomic analysis of features require an extended data set and should be the subject of a separate work. As shown in this paper, taxonomic methods can be a useful tool for studying the demographic past of the former Polish-Lithuanian Commonwealth and other areas with Polish-speaking populations.

\footnotetext{
${ }^{34}$ Okólski, Teoria, 99.

${ }^{35}$ Models of taxonomic, and other, issues are discussed in Józef Pociecha et al. Metody, 23-32.
} 


\section{Bibliography}

Analiza skupień - Internetowy podręcznik statystyki. http://www.statsoft.pl.

Błażejczyk-Majka, Lucyna. Zastosowanie wybranych metod taksonomicznych w badaniach historycznych. Poznań: Wydawnictwo Instytutu Historii Uniwersytetu im. Adama Mickiewicza w Poznaniu, 2018.

Chesnais, Jean-Claude. La Transition Démographique. Étapes, Formes, Implications Économiques. Paris: Presses Universitaires de France, 1986.

Cieślak, Maria, ed. Demografia. Metody analizy i prognozowania. Warszawa: Wydawnictwo Naukowe PWN, 1992.

Coale, Ansley J. The Growth and Structure of Human Populations. Princeton: Princeton University Press, 1972.

Domański, Czesław. "Jubileusz Polskiego Towarzystwa Statystycznego.” In: Tradycje a obecne zadania statystyki w Polsce, ed. Alexander Zeliaś. Kraków: Wydawnictwo Akademii Ekonomicznej w Krakowie, 2004.

Eberhard, Piotr. "Fazy rozwoju demograficznego Polski.” Roczniki Nauk Społecznych 42 (2014), 2: 135-160.

Grabiński, Tadeusz, Stanisław Wydymus, Aleksander Zeliaś. Metody taksonomii numerycznej w modelowaniu zjawisk społeczno-ekonomicznych. Warszawa: PWN, 1989.

Holzer, Jerzy Z. Demografia. Warszawa: Polskie Wydawnictwo Ekonomiczne, 2003.

Knodel, John E. The Decline of Fertility in Germany 1871-1939. Princeton: Princeton University Press, 1974.

Kolenda, Maria. Taksonomia numeryczna. Wrocław: Wydawnictwo Akademii Ekonomicznej we Wrocławiu, 2006.

Krzyżanowski, Adam, Kazimierz Kumaniecki. Statystyka Polski. Kraków: Polskie Towarzystwo Statystyczne, 1915.

Kurkiewicz, Jolanta. Modele przemian płodności w wybranych krajach europejskich w świetle drugiego przejścia demograficznego. Kraków: Wydawnictwo Akademii Ekonomicznej w Krakowie, 1998.

Kurkiewicz, Jolanta, ed. Procesy demograficzne i metody ich analizy. Kraków: Wydawnictwo Uniwersytetu Ekonomicznego w Krakowie, 2010.

Landry, Adolph. La Révolution Démographique. Études et Essais sur les Problèmes de la Population. Paris: Libraire du Recueil Sirey, société anonyme, 1934.

Młodak, Andrzej. Analiza taksonomiczna w statystyce regionalnej. Warszawa: Difin, 2006.

Notestein, Frank W. "Population. The Long View.” In: Food for the World, ed. T. Schulz. Chicago: University of Chicago Press, 1945.

Ogórek, Bartosz. Niezatarte piętno? Wpływ I wojny światowej na ludność miasta Krakowa. Kraków: Universitas, 2018.

Okólski, Marek. Demografia, Warszawa: Wydawnictwo Naukowe Scholar, 2005.

Okólski, Marek, ed. Teoria przejścia demograficznego. Warszawa: Polskie Wydawnictwo Ekonomiczne, 1990. 
Pociecha, Józef. "Demograficzny obraz ziem polskich w przededniu I wojny światowej." Wiadomości Statystyczne 7 (2019): 56-69.

Pociecha, Józef. "Powstanie Polskiego Towarzystwa Statystycznego w Krakowie: J. Leo - pierwszy prezes Towarzystwa.” Wiadomości Statystyczne 10 (2011): 1-9.

Pociecha, Józef. "Statistics of Poland - The First Yearbook of Polish Lands: Authors and Content." Acta Universitatis Lodziensis. Folia Oeconomica 5 (2018), 338: 229-245.

Pociecha, Józef, Barbara Podolec, Andrzej Sokołowski, Kazimierz Zając. Metody taksonomiczne w badaniach społeczno-ekonomicznych. Warszawa: PWN, 1988.

Polskie Towarzystwo Statystyczne 1912-1992. Warszawa: Polskie Towarzystwo Statystyczne, Rada Główna, 1992.

Rosset, Edward. Eksplozja demograficzna. Warszawa: Książka i Wiedza, 1978.

Rószkiewicz, Małgorzata. Model transformacji demograficznej. Teoretyczne uogólnienia oraz praktyczne implikacje. Warszawa: SGPiS, 1987.

Thompson, Warren S. "Population.” American Journal of Sociology 34 (1929), 6: 959975.

Zamorski, Krzysztof. "Początki przejścia demograficznego w Polsce.” Studia Demograficzne 2 (1993): 15-22.

Zamorski, Krzysztof. "Transformacja demograficzna $w$ Galicji na tle przemian ludnościowych innych obszarów Europy Środkowej w drugiej połowie XIX i na początku XX w. Kraków: Wydawnictwo Uniwersytetu Jagiellońskiego, 1991.

Zamorski, Krzysztof. “Transformacja demograficzna w Europie Środkowej w XIX w. Wewnętrzne podobieństwa i różnice.” Przeszłość Demograficzna Polski 19 (1994): $27-45$

\section{The Process of Demographic Transition in Lands of the Former Polish-Lithuanian Commonwealth and Other Areas with Polish-Speaking Populations, 1865-1912}

\section{Summary}

The work is devoted to tracing the demographic transition process in the area of the former Polish-Lithuanian Commonwealth, enlarged by areas with a predominantly Polish population, i.e., Upper Silesia and Cieszyn Silesia, along with Southern Masuria. The time frame of this article covers the period of the second half of the 19th century until the outbreak of World War I, more specifically the years 1865-1912.

The theoretical basis for the research is the theory of demographic transition, the principles of which are presented in the first part of the work. The source of the demographic data is the work by Adam Krzyżanowski and Kazimierz Kumaniecki Statystyka Polski [Statistics of Poland], published in Kraków in 1915, which is the result of the activities of the Polish Statistical Association established in 1912 in Kraków. 
The main part of the work is the analysis of changes in the basic indicators of the vital statistics of the population, namely, the intensity of deaths, the intensity of births and the intensity of marriages. The approximate beginning of the demographic transition process in individual districts of the analyzed areas and the approximate moment of transition from the second to the third phase of demographic transformation in the four-phase model of transition were determined.

The similarities and differences in the demographic situation on the eve of the outbreak of World War I were examined by distinguishing, with the use of taxonomic methods such as Ward's method and the $k$-means method, groups of territorial units similar to the changes in vital statistics. The grouping results indicate that the process of demographic transition in analyzed areas was diversified and was conditioned not so much by the state affiliation of these lands, but rather by the level of their economic development and their geographical location.

\section{Przebieg procesu przejścia demograficznego na ziemiach dawnego państwa polsko-litewskiego oraz na innych obszarach z polskojęzyczną ludnością w latach 1865-1912}

\section{Streszczenie}

Praca została poświęcona prześledzeniu procesu przejścia demograficznego na ziemiach dawnego państwa polsko-litewskiego, poszerzonych o obszary zamieszkane głównie przez ludność polskojęzyczną, tj. Górny Śląsk i Śląsk Cieszyński oraz Mazury Południowe. Zakres czasowy obejmuje okres drugiej połowy XIX wieku do wybuchu I wojny światowej, ściślej lata 1865-1912.

Podstawą teoretyczną przeprowadzonego badania jest teoria przejścia demograficznego, której zasady przedstawione zostały w pierwszej części pracy. Źródłem danych demograficznych jest praca Adama Krzyżanowskiego i Kazimierza Kumanieckiego Statystyka Polski, wydana w Krakowie w 1915 roku, będąca efektem działalności powstałego w 1912 roku w Krakowie Polskiego Towarzystwa Statystycznego.

Zasadniczą część pracy stanowi analiza zmian podstawowych wskaźników ruchu naturalnego ludności, czyli: natężenia zgonów, natężenia urodzeń oraz natężenia zawierania małżeństw. Wyznaczono przybliżony początek procesu przejścia demograficznego w poszczególnych dzielnicach ziem polskich oraz przybliżony moment przejścia z drugiej do trzeciej fazy transformacji demograficznej w czterofazowym modelu przejścia.

Podobieństwa i różnice sytuacji demograficznej na ziemiach polskich w przededniu wybuchu I wojny światowej zbadano, dokonując wyodrębnienia metodami taksonomicznymi, czyli: metodą Warda oraz metodą k-średnich, grup jednostek terytorialnych, podobnych ze względu na przebieg procesów ruchu naturalnego. Wyniki grupowania 
wskazują, że proces przejścia demograficznego na ziemiach objętych analizą przebiegał w sposób zróżnicowany i był uwarunkowany nie tyle przynależnością państwową tych ziem, ile bardziej poziomem ich rozwoju gospodarczego oraz położeniem geograficznym. 